\title{
Decolonizing hegemonic approaches of water: exploring Latin American proposals for communality and community
}

\author{
Denisse Roca-Servat \\ Juan David Arias-Henao \\ María Botero-Mesa
}

${ }^{I}$ Universidad Pontificia Bolivariana sede Medellín, Colombia.

II Universidad Pontificia Bolivariana sede Medellín, Colombia.

III Corporación Ecológica y Cultural Penca de Sábila and Universidad Pontificia Bolivariana, Medellín, Colombia.

\begin{abstract}
The current civilizational crisis raises challenges on the care of the commons, among them water occupies a crucial place. In this context it is essential to rethink water, from other epistemic and ontological approaches, that resist the determinism of neoliberal capitalism, the monoculture of modern eurocentric science and the anthropocentric-patriarchal domination of nature. Departing from Latin American political ecology, in first place, we carry out a critical review of hegemonic approaches to water. Then, we present two decolonial proposals for relating with the commons, in particular with water: communality, and community entanglements. Finally, the scope of these proposals is discussed as alternatives to the civilizational crisis, and their contribution to the understanding of water, from a decolonial, relational and ecological perspective.
\end{abstract}

Keywords: Political ecology, decolonize, water, communality, community entanglements.

São Paulo. Vol. 24, 2021

Featured Topic: Decolonial Insurgences and Emancipatory Horizons: Contributions of Political Ecology

DOI: http://dx.doi.org/10.1590/1809-4422asoc20200096r1vu2021L4TD 


\section{Introduction}

Water, as the source of life itself, is at a crossroads. Considered as a "strategic natural resource" by the global economic system, it plays a leading role in the socio-metabolic processes that sustain the urbanization of territories, as well as the expansion of automated technological processes and the configuration of a certain type of consumer subjectivity. All this is based on the exploitation of rural territories, from which "natural resources" are extracted for the production of commodities. These processes, mostly planned "from above", are characterized by arranging space-time to the benefit of mercantile and technoefficient interests, often in detriment, or even destroying, a diversity of ways of being and knowing the world. In this sense, the hegemonic model of "development" or "progress" (ESCOBAR, 2007) goes hand in hand with the linear logic of urban growth, promoting consumerist and modernizing "lifestyles".

Water supply under the neoliberal capitalist system, no longer understood only as a production model but as a hegemonic civilizing model (MACHADO, 2014), has given rise to a network of water infrastructure established around economic and social power (BOELENS; ARROYO, 2013) configuring bodies - territories at the disposal of that rationality. A rationality that ends up reproducing unequal water landscapes, multiple dispossessions (NAVARRO; TZUL, 2016), and recycled development discourses with new adjectives such as "green economy" or "sustainable development" (ESTEVA, n.d.).

In this context, it becomes indispensable to reflect on ways of caring for the commons from other shores in which relationships with water attempt to transcend the determinism of neoliberal capitalism and the political configuration of the nation-state, as well as the monoculture of modern Eurocentric science and the anthropocentric patriarchal domination of nature (LANDER, 2015; LEFF, 2009; SANTOS, 2011). All this, as Rivera-Cusicanqui (2010) indicates, from the very frontier of opposing poles. A frontier that does not imply either negotiating or adapting entirely to the hegemonic system, or an idealization or essentialism of resistance based on a vision of "static identities" but from a horizon where more autonomous alternatives to these models of socionatural relationships are constituted.

Rethinking our relationship with water requires making visible these other ways of conceiving and relating to the commons. In this sense, Latin American political ecology proposes the need to decolonize the hegemonic conceptions of nature, revealing the injustices that occur in contexts of unequal power relations. Moreover, there is also an interest in making visible the alternative proposals built and lived by communities and/ or social movements from other epistemologies and ways of being in the world. This perspective does not ignore the variegated or baroque character that characterizes these alternatives; on the contrary, it recognizes that they are the product of the juxtaposition of western modernity and of the indigenous, peasant or mestizo epistemologies and ontologies where they are reproduced (RIVERA-CUSICANQUI, 2010).

Through this encounter, always in contention, we present two Latin American proposals called "community entanglements" and "communality". Although both are nourished by the territorial experiences of mestizo and indigenous peoples, both urban and 
rural, from the states of Puebla and Oaxaca in Mexico, they are nested with experiences of other Mesoamerican and Andean peoples and the strength of the feminist movement in other Latin American latitudes. These two proposals are committed to the reproduction of life based on autonomy as a political project, which implies a critique of formal democracy and the political-legal regime of the Nation-State and full recognition of other forms of government and cultural political practices. In this sense, these proposals consider it crucial to combine freedom and the capacity to determine their own spaces, respecting other cultural and political forms based on an intercultural dialogue that transcends the totalitarianism of the Nation-State (ESTEVA, 2011).

For the interpretation of both proposals, we started from a decolonial methodological approach that initially carried out a systematic study of the written production of both currents emphasizing their origins, epistemic assumptions and conceptions about water. This information was complemented with stays in the territories during the months of February and March 2018 that involved understanding the narratives linked to communal struggles in their own terms. Thus, unstructured interviews and informal conversations were conducted with several people practicing these two experiences. In a first moment, contact was made with the knowledge and experiences of communities related to the struggle for water in Oaxaca, as well as with intellectuals/activists participating in the "Caminos de la Autonomía bajo la Tormenta" encounters of Universidad de la Tierra; and, in a second moment, conversations were held with researchers/activists of "Seminario de Entramados Comunitarios y Formas de lo Político" in Puebla, Mexico.

The analysis and corroboration of the results included the review of audiovisual and textual material from academic events and Latin American meetings whose purpose revolved around these experiences, as well as the organization of spaces for reflectionaction ${ }^{1}$. Additionally, a draft version of this paper received comments and feedback from experts and scholars of these experiences, although the arguments expressed in this work are the sole responsibility of the authors. Finally, the exercise of constant and collective interpretation, as well as critical reading, allowed for the triangulation of the results among the authors of this paper.

Below, we first present a political ecological study of the hegemonic conceptions of water. Secondly, we present two Latin American alternatives of hydrosocial relations, which show other ways of conceiving the commons, through the proposals of communality and community entanglements. We conclude with some reflections on the scope of these proposals as alternatives to the civilizational crisis and their contribution to the understanding of water from a decolonial, relational and ecological perspective.

\section{Decolonizing hegemonic approaches of water}

Latin American political ecology, as a field of inter- and transdisciplinary studies, is

1. Spaces such as: a) SLAD "Ecología Política y Bienes Comunes" 01 and 02 nov 2018 Medellín, Colombia, b) I Encuentro Latinoamericano de Territorios Hidrosociales 31 oct 2018 Colombia, c) Mesa Redonda "La defensa de los comunes: miradas desde la ecología política” 14 sept 2020 Medellín, Colombia, among others. 
distinguished by its interest in the perspective of decolonial thinking (MOREANO et al., 2017), whose role is to understand the relations of exploitation/appropriation of diverse forms of life, in addition to helping to make visible the struggles and alternative ways of living and inhabiting the territories. Decolonial thinking suggests that the domination suffered by the peoples of the global South did not finish with the end of colonialism but was configured as a matrix of power that has allowed the reproduction of the coloniality of power, knowledge, being and nature (PARRA-ROMERO, 2016).

For Alimonda (2011), colonial violence profoundly marked Latin America and especially the ways in which nature is understood as something susceptible to be exploited and shaped. Following this reflection, Machado (2012) argues that there is a new form of coloniality arising from the consolidation of neoliberalism and extractivism, which has very powerful effects on territories, bodies, biodiversity and subjectivity. Porto-Gonçalves (2017), in turn, analyzes the way in which the dualism between the rural and the urban has been configured through a coloniality of knowledge/power, which is expressed through a "metabolic rupture" between society and nature, in which the countryside has been subordinated in a modern-colonial manner to the city.

Through these approaches, Latin American political ecology argues, as Toro and Martín (2017) point out, that it is necessary to overcome the modern colonial concept of "natural resources", which embodies a deep anthropocentrism and sustains the functionalist idea of nature as a resource available to capital. In its place, lies the notion of "the commons", which implies that nature cannot be privatized in any way. In this sense, Latin American political ecology enters into the dispute over the multiple ways in which nature, the commons and especially water can be understood (ROCA-SERVAT, 2020). The idea of water as a "commons", places at the center of the discussion its communal character, its potential as an axis of social and political organization, its relational dimension as a means to guarantee the reproduction of life, and the opportunity to build decolonial experiences in relation to it.

In order to decolonize our relations with water, we start by questioning the three dominant approaches to respond to the civilizational crisis: water as a commodity, as a human right and as a common good (differentiating it from the broad notion of the "commons" and concentrating the critique on the institutionalist vision as will be described below) all within the framework of state - market - society relations (ROCA-SERVAT; BOTERO-MESA, 2020). Although in reality there are crossovers and interactions between hegemonic and counter-hegemonic approaches, we believe it is necessary, in this opportunity, to explore the limits and contours, as well as the modes of co-optation and straitjackets of hegemonic water discourses, which as an amalgam of rhetorical discourses end up being reduced to institutional or corporate recipes of individual or private interests when implemented in practice. Such an exploration, paraphrasing Esteva and Guerrero (2018), could enrich our perception of the present, revealing what has been hidden by modernity and opening horizons for reflection and action.

First, the discourses of green economy, eco-efficiency and environmental economics advocate the idea of water as an economic good or commodity. This approach, dissemi- 
nated by the Global Water Partnership (GWP, 2012) reduces decision-making on the relationship with nature to economic motivations and, given the complex bio-physical characteristics of water, promotes "Integrated Water Resource Management" (IWRM) and "water security" as strategies for harnessing the productive capacity of water. In this way, water is declared a central pillar of the green economy (SIWI, 2011) within the framework of sustainable development. In practice, this conception has several limitations, among them: it reduces its purpose to developmentalist logics of industrialization and modernization; it reinforces the state vision weakening and ignoring community and local water management; it does not take into account cultural, historical and political processes of its own; it sometimes serves as a façade to hide other political agendas; it is vague and confusing to the point of appearing rhetorical at times (GUEVARA, 2019). Thus, the watershed becomes a place of strategic importance for territorial planning capable of stimulating commercial development in the logic of payment for environmental services (ISCH; GENTES, 2006).

Secondly, a global anti-privatization movement has been consolidated to promote the conception of water as a human right and its incorporation into national and international regulations (SERRANO et al, 2012). This approach is based on a strong confidence in the potential of state law to define realities, which is based on the conception that the nature-society relationship is mediated by the positivization or regulation of the modern social contract, the role of the Nation-State and the anthropocentric vision of the normative system. However, this legal framework has not been translated into practices that necessarily respond to the aspirations of local struggles for water justice. This is because, on the one hand, the discourse of the human right to water in the framework of colonial relations becomes a rhetorical instrument (BOTERO-MESA; ROCA-SERVAT, 2019), and on the other, economic forces and the role of transnational corporations significantly influence access to this right, including guaranteeing it within the market logic (BAKKER, 2014).

Finally, institutionalist approaches have promoted the conception of water as a common good. The ecologist Hardin (1968) affirms that these are resources of common use to which a process of degradation is inherent, given that in situations of scarcity, individuals tend to increase their selfish behavior. For the author, this tragedy is only avoidable through an institution such as public or private property that prevents free access in which each individual pursues their own self-interest. This approach was discussed by Ostrom (1990), who sought not only to overcome the public-private dichotomy by demonstrating successful cases of community governance but also to show that access to these resources depended on the rules established and the capacities generated by coowners or co-users. However, this perspective does not fail to perceive water as a shared thing or resource, collectively managed through a series of institutional processes (rules, institutions, agreements) arranged for human use. In this sense, some critical studies on this perspective point out the little recognition to the historical-geographical conditions of each experience, the insufficient attention to power relations, the emergence of conflicts and the configuration of states, its tendency to emphasize issues of efficiency and functionality, as well as the limited political potential of the proposal to glimpse 
horizons of transformation beyond capital and institutionalism (DOWBOR et.al., 2018; SAUNDERS, 2014).

\section{Other communal hydrosocial relationships in Latin America}

Since the beginning of the 21st century, autonomous processes have promoted a broad debate on what it means to build alternatives to modern colonial capitalism, weaving horizontal, cooperative and autonomous relations from the local level (ADAMOVSKY et al., 2011). Below are two contributions influenced by this autonomic current, born in Latin America in the context of dialogues between communities, social movements and critical academia, which reveal concrete contributions to the task of decolonizing human relations with nature, in this case with water (ROCA-SERVAT; PALACIO OCANDO, 2019). These proposals are: community entanglements and communality.

\section{Community entanglements}

Understanding the rhythms and movements of struggles in Latin America implies reflecting on time as a philosophical thread that runs through the reproduction of life (GUTIÉRREZ, 2008). This is the call made by this theoretical-practical proposal born in the very struggle to live despite the confinement of emancipatory ideas, and the increasingly distant gaps between those who can live with dignity and those who cannot. This proposal arises from reflecting on the spatio-temporal scales of the political and of life in the midst of antagonistic and fragmentary situations, in concrete places, such as in the Andean region, particularly in Bolivia (GUTIÉRREZ, 2008; LINSALATA, 2010; 2014), and in southern Mexico (GUTIÉRREZ, 2006; 2007), among others. These reflections were knotted, and this is how the Permanent Seminar on "Community Networks and Forms of the Political" began in 2011 at the Benemérita Universidad Autónoma de Puebla in Mexico facilitated by Raquel Gutiérrez, Lucía Linsalata and Mina Lorena Navarro (GUTIÉRREZ et al., 2016; GUTIÉRREZ, 2018).

The communal-popular, instead of a rigid theoretical concept, constitutes a way of reading or understanding the struggles that allows distinguishing the singularities and the possibilities of connection and of horizontal recognition of those same particularities with other experiences (GUTIÉRREZ; MATAMOROS, 2016). All this, focusing attention on its contradictions and antagonisms (NAVARRO; GUTIÉRREZ, 2018). The Seminar works collectively to make visible "the diverse and polymorphous way in which diverse human, indigenous and non-indigenous communities, strive to struggle in a daily and extraordinary way to guarantee the material and symbolic conditions of their own (re) production, through political practices" (GUTIÉRREZ et al., 2019, p. 32) These political practices are called the "production of the common" (GUTIÉRREZ et al., 2016).

The production of the common implies understanding that the common is not simply a thing but is produced through collaborative social relations. The common is not something given, once and for all, but part of an ongoing process of constant revision and recreation (GUTIÉRREZ et al., 2016). Under this perspective, the commons are neither a thing, nor a good, nor a set of tangible goods, nor a simple community management 
strategy, but aim at deep transformations in social relations and at being an alternative to capitalist society (CAFFENTZIS; FEDERICI, 2015). These political forms contest the logic of capitalist modernity. In that sense, the common is thought from what is not fully subsumed by the logics of accumulation, that is, it is not thought from capital, but not ignoring it either (GUTIÉRREZ et al., 2016).

The community entanglements are the emancipatory face of the last decade of intense protests throughout Latin America, where social movements have developed a remarkable "veto power" in the face of the effects of neoliberal policies, the logic of capital and state force (GUTIÉRREZ, 2012). These struggles are not simply "resistances", but, after questioning capitalist accumulation, they open a communal form of politics that puts in check liberal politics and the possibilities of capital accumulation in the name of progress and development (GUTIÉRREZ, 2001). In opposition to the idea of a political restructuring through the State that was proposed by the "progressive" governments of the region, the politics of the common that emerges from the communal entanglements consists of establishing that which must be collectively reappropriated, and likewise, it seeks to question the centralizing and hierarchical command that enables the monopoly of decisions by the State (GUTIÉRREZ, 2017). Thus, there is a difference between the public and the common that cannot be missed: the public is controlled by the State, the common by the community.

Following this line, Gutiérrez (2017) states that the communal cannot be understood simply as that which is part of the primitive past, but as a possible present here and now, in the flow of concrete actions of reproduction of the present life. According to Navarro and Tzul Tzul (2016), the production of the common, understood as the strategies to reproduce life, is not something that can be explored only as part of the indigenous communities of the past, "the communal is not exclusively indigenous nor is the indigenous something essential" (p. 10). Therefore, even in urban communities, spaces where community entanglements are built can be appreciated, since the fact that capital and the State have a greater capacity to penetrate the different environments of life in the city, does not imply that there are no relations of solidarity, interdependence and cooperation among its inhabitants (NAVARRO, 2016).

Likewise, it is essential to point out the way in which community entanglements question the patriarchal and sexist dimension of the liberal form of politics. In this way, Gutierrez (2017), states that the production of the common is based on a "we as women", questioning the patriarchal and individualistic logic of the modern codes of the "I" in which the way of doing politics of the Nation-State is ascribed. The politics of community entanglements implies a decentering of the individual, the white man, and the modern state as the privileged subject of political action and moving towards the construction of a plural and diverse subject that recognizes the role of women in the care and reproduction of the commons (CAFFENTZIS; FEDERICI, 2015, p. 59). In that sense, feminist political practices are crucial for the social and everyday reproduction of life (NAVARRO; GUTIÉRREZ, 2018).

Finally, thinking the common also entails a way of organizing the terms of the in- 
terdependence of human and non-human life. The dialogue with ecology has been very important to try to go beyond the Cartesian thought that splits society and nature, and the totalizing and determining capitalist logic. Under these views, Gutiérrez and Navarro (2019) indicate "the creative and productive processes that sustain human and non-human life on a daily basis, as well as the set of activities and tasks aimed at procreation and support of the following generations, remain hidden and are considered "anomalous"” (p. 300-1). Hence the importance of recognizing the large volumes of work and energy performed by women and other companion species.

\section{Water and community entanglements}

In the case of water, several struggles provide a glimpse of the emancipatory horizon of community entanglements in its defense and care. For example, Linsalata (2014) shows the capacity of neighborhood meetings in Cochabamba, Bolivia, to preserve or reappropriate the management of collective life through their struggle for water. In this case, the assemblies of Villa Pagador in Cochabamba made it possible to bring water to their neighborhood by sharing work shifts among families in the community, contributing fees and materials, sharing past experiences and knowledge, and practicing doing together. These "social grammars", as Linsalata (2014) calls them, are the daily practices and wisdom that allow neighbors to manage, assembly after assembly and working collectively, to manage in a self-managed way the territory and water in urban contexts, breaking with both state and private logic.

Another example is the situation of the Maseual communities of the municipality of Cuetzalan del Progreso in Puebla, Mexico, which, in the course of a long process of struggle in defense of their territory, have managed to produce a participatory land-use planning and a capacity to directly manage different common issues and produce collective decisions (LINSALATA, 2017). Threatened by the growing mining-energy and tourism extractivism in their territories, and the affectation of their waters, these communities articulated themselves in the form of Assemblies in Defense of Territory and Life. These Assemblies made it possible to recover collective control over vital aspects for the communities, such as the regulation of land use and the restriction of economic activities such as mining that affect the territory, the defense of community water management, and the organization of collective security through everyday practices. Water for these communities is At Yoltok ${ }^{2}$, i.e., the "vital force capable of connecting the different dimensions that structure the maseual world" (LINSALATA, 2018, p. 149). Water feels, it is a sexed entity, it has its guardians and beings that protect it, it can heal as well as get angry and kill (2018). Water is not only indispensable for life, but it is alive, and it is produced and protected from a complex web of daily and community relationships (LINSALATA, 2018).

On the other hand, Navarro (2015a) illustrates the example of different women community members such as Estela Chávez of the Council of Peoples in Defense of the Río Verde (CoPudeveR), who, in the face of the possible implementation of a new hy-

2. In the náhuatl language of the Sierra Norte in Puebla it means "water that as alive, water that feels, water that haves a heart" (Linsalata, 2018: 147). 
droelectric project in their territory, mobilize collectively to regenerate and strengthen the social relations that guarantee the care of water. Women, as this proposal indicates, play a crucial role in promoting and generating forms of production of the commons and reproduction of life. In this way, they recognize that the effects on water are not only due to decreased access or deterioration of water quality, which can cause diseases and undermine livelihood economies, but that water contamination also breaks the social fabric. Hence, women community members such as Sofía Enciso of the community organization "Un Salto de Vida" explain the profound connection between river preservation and the restructuring of the social fabric.

In cities, on the other hand, contrary to the dominant common sense that defines them as neoliberal spaces of a sum of self-sufficient and fragmented individualities, forms of the common are also produced against and beyond capitalism and state dependence (NAVARRO, 2016). An example of urban struggle is the one promoted by the Asamblea Social por el Agua de Colonos del Valle Dorado de Puebla. In this case, they faced strategies of electoral and populist co-optation by different political parties who tried to solve the problems they had with the water service. However, as mentioned by one of the members of the Assembly, what they could not take away from them was the friendship and the core of good relations and affection they had built among the neighbors (NAVARRO, 2016). These relationships made visible the "black holes" in the system, revealing the complex contradictions with state institutions. This experience is part of the recognition that what unites them is not a particular ideology, but a common problem: decent housing and water. In this way, Navarro (2016) shows how the common in the city is also produced in practice, through ways of organizing cooperation, deliberation and decision, despite the prevailing logic of separation and fragmentation.

\section{Communality:}

Communality is a way of being and living that can be illustrated from the experience of the peoples of the mountains of Oaxaca, Mexico (MALDONADO, 2016; ESTEVA; GUERRERO, 2018). Although the people of the villages themselves do not speak daily of "communality", the concept was proposed in the 1970s by Floriberto Díaz and Jaime Martínez Luna, two Oaxacan intellectuals who graduated as anthropologists, and raised it to explain to outsiders the experience of communal life (PINEDA, 2017; GUERRERO, 2013). Thus, the concept of communality was not only an inspiration of individual authors, but the result of a much broader process of organization and community struggles (PINEDA, 2017; GUERRERO, 2013).

As a contemporary way of life, communality incorporates what comes from outside without allowing the own to be destroyed or dissolved (ESTEVA; GUERRERO, 2018). Thus, it is important to clarify that it does not refer only to life in the local area of Oaxaca (although the concept was born there), but in a general way to the way in which life is organized in many communities throughout Mesoamerica (PINEDA, 2017; MALDONADO, 2013). Traditions of many peoples that through a "stubborn resistance" have managed to persist "to remain what they are despite the pressures to dissolve them, 
reduce them, turn them into something else, and develop them" (ESTEVA; GUERRERO, 2018, p. 34). Thus, the "community" is not part of a distant past but persists under very diverse conditions and for historical and geographical periods that are very distant from each other, which gives it an organic character of high dynamism, which is constantly reproduced and transformed (ESTEVA, 2015).

Communality implies a way of seeing and contributing through which it is possible to recognize, invigorate and learn what is communal and it is built from the feeling-thought and oral history. In the case of the Oaxacan mountain communities, it entails recognizing the daily and concrete life built from their knowledge and actions of resistance, in space-times such as the territory, the assembly, the tequio and the festival (MARTíNEZ $\mathrm{L}, 2013)$. For these communities, communality is expressed through various forms of collective work. An example of this is the "tequio", an effective form of work organization that is developed without any monetary compensation and is linked to other types of values such as the prestige of the local inhabitants or the commitments acquired by living in the community (FUENTE C et al., 2015; MARTÍNEZ L, 2013). Tequio is, at the same time, a tool for the survival of the people, which functions as a counter-power against the demands and economic support that local communities receive from the State (PINEDA, 2017).

Communality raises the need for an epistemology different from the Western one, where the imperative is not knowledge that tries to discover the truth, but where the astonishment of one's own is sought (GUERRERO, 2013). It is a form of mobilization of communities around an exercise of a character based on "self-management, power, economy, care of the environment, health, social reproduction, conflict resolution, etc. That is why it is the basis for the reorganization of the nation based on autonomy" (MALDONADO, 2013, p. 27). This requires bringing politics, together with ethics, back to the center of life, displacing economics (ESTEVA, 2015) in order to move towards much more plural and diverse worlds.

The communal aspect of this proposal functions as an effective response to the growing wave of violence, misgovernment, authoritarianism, and uncertainty produced by global capitalism (ESTEVA, 2015). Communality is based on the rejection of all imposed forms of government, even that which has been called "representative democracy". In opposition to this, communality appeals to the exercise of a government of situations from the community level and aims to build institutions with communal principles (MARTÍNEZ L, 2013). In this way, the community is organized to exercise power through direct participation in decisions on matters affecting the local level. Thus, "the concept of communal citizenship is diametrically different from that of national citizenship. And it is treated from the communality of something that is built with many years of work, of expenditure, of feeling the pleasure of being a community" (MALDONADO, 2013, p. 27). The communal does not exist previously, but is the result of daily work, orality, and celebration (MALDONADO, 2013).

Communality works through principles that can be pointed out as: work at the service of the community, respect, and recognition of the other in the totality of life, and 
reciprocity and interdependence (MARTÍNEZ L, 2013; FUENTE C, 2012). Another of these fundamental principles for communality is responsibility, since "communal life is an impressive, deinstitutionalized school in which young people and adults are trained in responsibility" (MALDONADO, 2013, p. 25). In addition to these principles, communality is constituted from three elements: a structure that is the community, a form of organization that is communality, and a form of learning that is that of the spiral movement or that of sharing or guelaguetza in Zapotec (ESTEVA; GUERRERO, 2018; MALDONADO, 2016; MALDONADO, 2013).

\section{Water and communality}

Communality positions a form of social organization that provides an alternative vision to the hegemonic rationality of water. As Esteva (2011) argues, the relationship with water should respond to a recovery of traditional practices but combining them with contemporary practices. Thus, he invites to recover the "sense of proportion" in the use of water, which does not mean going back to prehistory, but the recognition and respect for its cycle, and an awareness of the real possibilities of using water in the basin where each community recreates its ways of life. In this sense, we must recognize that "we are water, almost literally, and water is life. We have always known this and have acted congruently with this awareness. Every time a human group lost sight of such elemental wisdom, they paid a very high price" (ESTEVA, 2011; p. 9). Water from this proposal has a tangible and intangible character (MALDONADO, 2013), it is a mysterious entity, with its own life and freedom (ESTEVA, 2016, p. 173).

As pointed out by Fuente $C$ et al. (2015), through the experience of social organization of the populations of Benito Juárez, in Oaxaca (Mexico), it is possible to observe an example of how to understand water from communality. In this type of case, the water practices of peasant communities allow them to relate to water from a logic of communality that promotes greater care and responsibility in social and environmental terms (HERNÁNDEZ, 2012). Thus, this particular community is organized according to a local normative system, where the laws are made by its own inhabitants, where the highest authority is the assembly formed by them, and where decisions on events of common interest are made. From there, a communal management is developed, in which there is an alternative cosmovision of the right to water, where all people must have access to it and no one can be denied it, nor can it be priced. In addition to this, infrastructures such as tanks and pipes are community property (FUENTE C et al., 2015; HERNÁNDEZ, 2012).

In the case of Benito Juárez, they have sought to make an adequate use of water, developing an ethics of care in which the quantities and qualities of the vital liquid are regulated, avoiding waste as much as possible and developing reuse techniques. Through the assembly, strict control rules have been decided that have allowed the community to have water supply throughout the year. These agreements are not exempt from debates, but rather, they are "aggregates of hearts" where decisions on community water management are born and mature in contradiction and antagonism (GUERRERO, 2013, p. 49).

As Guerrero argues, the relationship of collaboration, acceptance, resistance, and 
domination with external powers to the community (State and market), is often tense and contradictory: "an external imposition generates and faces internal resistance, and the resulting adaptation is what we are, the communal Us. The imposition can be violent or subtle. Resistance does not always occur, and it is also accepted and collaborated" (2013, p. 114). That is why agreements developed in association with the State on water management are continuously being modified. As expressed by Fuente C et al., (2015), years after the implementation of a government program, the community of Benito Juárez noticed that water was being wasted and decided to apply a little collective effort to be able to maintain water for a longer time and that would allow covering the basic need of families, adjusting agreements established in the state program.

\section{Final Reflections}

In the current context of civilizational crisis, it is necessary to decolonize our relationship with nature, which implies a capacity to subvert the processes of internal colonization, and at the same time accept that we coexist with them. (RIVERA-CUSICANQUI, 2010). This perspective makes it possible to question the hegemonic visions of water or when these visions become "dead words" because they silence concerns and do not allow us to see the contradictions they harbor. We find, therefore, that water in the global economic system is understood as a service or a commodity, being reduced to a strategic natural resource fundamental for "development". Likewise, the process of decolonizing requires reflection on the materialization of the human right to water within the framework of market rules, the power of transnational corporations, and the limits of state and anthropocentric law. Likewise, it allows us to identify the contours of the discourses of water as a common good, which often fall back on the modern conception of the construction of institutions, the commodification of nature, and the invisibility of power relations.

It is important to point out that, both within and outside the decolonizing experiences, there is a contradictory relationship with institutions such as the State, the Churches, NGOs, or the market. In turn, tensions within community experiences are very diverse and are related to power games and the reproduction of domination forms within and between communities (GUERRERO, 2013). This paradoxical situation does not entail paralysis or a dichotomy between opposites, but a complex middle ground that cannot be reduced to a simple symbiosis or fusion of opposites, nor to hybridization ${ }^{3}$ (RIVERA-CUSICANQUI, 2011). Similarly, the relationship with the outside implies, on some occasions, conflict, and resistance and, on others, dialogue, and negotiation. However, the latter does not mean that we start from the same point in the understanding of the problem, nor that we manage to speak the same "intercultural" language or that we believe in the legitimacy of "external powers". From this autonomous vision, negotiations with these actors are practiced "in opposition to the dominant regime and

3- To deepen this discussion, it is suggested to review the terms "motley" by René Zavaleta and "ch'ixi" by Silvia Rivera Cusicanqui. 
are continually exposed to contradiction and dissolution" (ESTEVA, 2011a, p. 122). Far from being simply a relationship of agreements and complex collaboration with the State, these experiences question the modern and colonial vision of water management.

On the other hand, Latin American political ecology also reveals different relationships and meanings of water that go beyond financial, colonial, and patriarchal logics. From this point of view, it is possible to understand that water is not only immersed in relations of exploitation and appropriation, but also in the middle of different ways of living, practicing and inhabiting territories that go in the direction of decolonial hydrosocial relations. This implies that it is necessary to make visible other epistemic (of knowledge) and ontological (of being) forms about water that go beyond reductionist logics, and that make it possible to understand other possible worlds.

In this sense, the two proposals presented show us hydrosocial relations that open horizons in their decolonial, relational and ecological understanding. Both start from a decolonial position that considers the environmental history of each particular place, the contradictions of the capitalist system, and the anthropocentric rationality of modernity. On the one hand, communality recognizes the history of dispossession and the obligatory relationship with the conquest, the state, and the exploitation of nature that Oaxacan communities have suffered. And, on the other hand, community entanglements are based on the struggle as an antagonistic space where political decisions and community organization are produced. The commons, from these perspectives, are understood as relationships, not as "things", or as goods with exchange values, or as "objects" to be guaranteed by the State or the market.

From a relational point of view, both claim in one way or another the community self-management under their own standards, which often enter into tension with those defined by the State and the market. These other ways of constructing commons make visible different relationships and meanings of water, which draw our attention because of their commitment to the reproduction of life. From the point of view of communality, the relationship with water must respond to a recovery of traditional practices but combining them with contemporary practices. From this proposal, water is material and spiritual, sensual, and intellectual, it has power and meaning, all in one (ESTEVA, 2016). From the key of community entanglements, cooperative relationships are established and organized, through links and actions that have to generate forms of care for life that are not exempt from difficulties. Water has a multiplicity of meanings, i.e., a qualitative diversity of use values (LINSALATA, 2018).

Thinking in ecological terms, both proposals suggest the need to understand the interdependencies and ecosystem interrelationships to which human beings belong on planet Earth. In turn, from community entanglements, we can appreciate practices of interdependence with water that bet on its care, taking into account the reproduction of the material and symbolic life of humans and non-humans. Likewise, from the communality, it is emphasized that water care is a common responsibility, and that this implies conserving the natural water sponges, as well as seeking alternatives to modern sanitary models.

These proposals also have differences, we would like to highlight a couple of them. 
On the one hand, the proposal of community entanglements focuses more directly on the role of women in the struggle for the reproduction of life. In this sense, they make visible the ways in which the patriarchy has hidden the set of activities and material, affective and symbolic activities sustained by women and other species. This does not mean that the proposal of communality does not take this into account, but rather that it has another point of entry. On the other hand, the proposal of communality emerges from a place of enunciation more obviously outside or in tension with the logics of development inserted in the different areas of life, including academia and institutional education. Community entanglements, on the other hand, are attempting a dialogue from an academy committed to the struggles of communities, women and the various collectives built "from below".

In conclusion, both proposals suggest important alternatives in the face of the civilizational crisis we are experiencing. They show in an articulated and rigorous manner the experiences and hopes of diverse and plural peoples struggling for a dignified life in the territories. These proposals, as Rivera-Cusicanqui (2017) would say, require us to overcome essentialisms, manipulative, and rhetorical maneuvers of hegemonic discourses to rather practice decolonization in everyday life. Today more than ever we are called to defend, safeguard, and promote hydrosocial relations that establish decolonial, solidaritybased, anti-patriarchal and interdependent practices.

\section{Acknowledgement}

We would like to thank Mina Lorena Navarro and Gustavo Esteva for their valuable feedback to a first draft of this text. We would also like to thank the blind peer reviewers for their comments. This research is part of the project "Ecología Política y pensamiento ambiental desde América Latina / Abya Yala - CLACSO" with file number 775B-06/17-12 at the Centro de Investigaciones para el Desarrollo Integral (CIDI) of the Universidad Pontificia Bolivariana, Medellín, Colombia.

\section{References}

ADAMOVSKY, E., ALBERTANI, C., ARDITI, B., CECEÑA, A. ... ZIBECHI, R. Pensar las autonomías. Alternativas de emancipación al capital y el Estado. Bajo tierra ediciones. - $1 \stackrel{\underline{a}}{\text { ed. }}$ eMéxico D.F:: Sísifo Ediciones, Bajo Tierra, 2011.

ALIMONDA, H. La naturaleza colonizada. Buenos Aires: CLACSO - Consejo Latinoamericano de Ciencias Sociales, 2011.

BOELENS, R; ARROYO, A. Introducción: El agua fluye en dirección del poder. En: BOELENS, R; ARROYO, A. Ed. Aguas Robadas. Despojo hídrico y movilización social. Quito: Justicia Hídrica, Abya Yala, Instituto de Estudios Peruanos, 2013. p. 17-26. 
BOTERO-MESA, M; ROCA-SERVAT, D. Water Rights and Everyday Ch'ixi Practices in the Barrio El Faro in Medellín, Colombia. Water. 2019; 11(10):2062. https://doi.org/10.3390/ w11102062

CAFFENTZIS, G; FEDERICI, S. Comunes contra y más allá del capitalismo. El Apantle. Revista de Estudios Comunitarios, v.1, p. 51-72, 2015.

DOWBOR, L; ESTEVES, A; PANEZ, A. "Reapropiaciones de los bienes comunes: miradas críticas en torno a la gobernanza hídrica." Revista Rupturas, v. 8, n. 2, p. 33 - 57, 2018.

ESCOBAR, A. La invención del Tercer Mundo. Construcción y deconstrucción del desarrollo. Venezuela: Editorial El perro y la rana. 2007.

ESTEVA, G. Desarrollo. s.f. Disponible en: https://desarrolloxxi.files.wordpress.com/2010/05/ desarrollogustavoesteva1.pdf

ESTEVA, G. Otra Autonomía, Otra Democracia. En: ADAMOVSKY, E., ALBERTANI, C., ARDITI, B., CECEÑA, A. ... ZIBECHI, R. Pensar las autonomías. Alternativas de emancipación al capital y el Estado. Bajo tierra ediciones. -1ํㅡㄹ ed.- México D.F.: Sísifo Ediciones, Bajo Tierra, 2011a

ESTEVA, G. Prólogo. En: LÓPEZ, L. Las reflexiones de Aguaxaca: repensar el agua. México: INSO-Carteles editores -Fundación Alfredo Harp Helú Oaxaca-Fundación Gonzalo Rio Arronte, IAP. 2011b.ESTEVA, G. Para sentipensar la comunalidad. Bajo el volcán, v. 15, n. 23, p. $171-186,2015$.

ESTEVA, G; GUERRERO, A. Usos, ideas y perspectivas de la comunalidad. En: Comunalidad, tramas comunitarias y producción de lo común. Debates contemporáneos desde América Latina, GUTIÉRREZ, R (Coord.) Oaxaca, México: Colectivo Editorial Pez en el Árbol, Editorial Casa de las Preguntas. 2018.

FUENTE CARRASCO, M. La comunalidad como base para la construcción de resiliencia social ante la crisis civilizatoria. POLIS, Revista Latinoamericana, v. 11, n. 33, p. 1-16, 2012.

FUENTE CARRASCO, M; TAGLE ZAMORA, D; HERNÁNDEZ MECINAS, E. La justicia ambiental como atributo del ecosocialismo. Exploraciones teóricas y praxis comunitarias en la gestión del agua. Theomai, n. 32, p.170-188, 2015.

GUERRERO, A. La comunalidad como herramienta: una metáfora espiral. Cuadernos del sur, n. 34, p. 39-56, 2013.

GUEVARA, V. Revisión crítica de los alcances y límites de la Gestión Integrada de Recursos Hídricos (GIRH): el caso de la subcuenca Santa Eulalia. Revista Kawsaypacha: sociedad y medio ambiente, n. 4, p. 25-45, 2019.

GUTIÉRREZ, R. Forma comunal y forma liberal de la política: de la soberanía social a la irresponsabilidad civil. Pluriverso. Teoría política boliviana. 2001. 
GUTIÉRREZ, R. Sobre la VI Declaración de la Selva Lacandona y La Otra Campaña. Bajo el Volcán, v. 6, n. 10, p. 73-84, 2006.

GUTIÉRREZ, R. Algunas preguntas para los compañeros del EZLN. Carta de Raquel Gutiérrez Aguilar. Bajo el Volcán, v. 7, n. 11, p. 107-113, 2007.

GUTIÉRREZ, R. Los ritmos del Pachakuti. Movilización y levantamiento indigena-popular en Bolivia. Buenos Aires: Tinta Limón. 2008.

GUTIÉRREZ, R. Más allá de la 'capacidad de veto': el difícil camino de la producción y reproducción de lo común”. En: GUTIERREZ, R. Horizonte comunitario-popular. Antagonismo y producción de lo común en América Latina. Puebla: Benemérita Universidad Autónoma de Puebla, 2012. p. 101-116.

GUTIÉRREZ, R. Horizontes comunitario-populares. Producción de lo común más allá de las políticas estado-céntricas. Madrid: Traficantes de sueños, 2017.

GUTIÉRREZ, R. Comunalidad, tramas comunitarias y producción de lo común. Debates contemporáneos desde América Latina, Oaxaca: Colectivo Editorial Pez en el Árbol, Editorial Casa de las Preguntas. 2018.

GUTIÉRREZ, R; MATAMOROS, F. A manera de prólogo. En: LINSALATA, L. editor. Lo comunitario-popular en México: desafíos, tensiones y posibilidades. Puebla: Instituta de Ciencias Sociales y Humanidades" Alfonso Vélez Pliego", Benemérita Universidad Autónoma de Puebla; 2016.

GUTIÉRREZ, R; NAVARRO, M. Producir lo común para sostener y transformar la vida: algunas reflexiones desde la clave de la interdependencia. Confluencias, v. 21, n. 2, 2019.

GUTIÉRREZ, R; NAVARRO, M; LINSALATA, L. Repensar lo político. Pensar lo común. Claves para la discusión. En: Modernidades Alternativas. INCLÁN, D; LINSALATA, L; MILLÁN, M. (Eds). México: Ediciones del Lirio. 2016.

GUTIÉRREZ, R; LINSALATA, L; NAVARRO, M. El trabajo colectivo del Seminario Permanente "Entramados Comunitarios y Formas de lo Político" para el dossier por una sociología desde abajo. Confluencias, v. 21, n. 2, 2019.

GWP. Documento de perspectiva. Agua en la Economía Verde [Internet]. 2012 [Consultado el 25 Mar 2020]. Disponible en: www.gwptoolbox.org

HARDIN, G. La tragedia de los comunes. Science, v. 162, n. 37, p. 1243-1248, 1968.

HERNÁNDEZ, E. La gestión del agua para uso doméstico desde la perspectiva comunitaria. Caso de la Comunidad de Benito Juárez, Sierra Norte de Oaxaca. Tesis de Licenciatura en Ciencias Ambientales de la Universidad de la Sierra Juárez. 2012.

ISCH, L; GENTES, I. Agua y servicios ambientales: visiones críticas desde los Andes. Ediciones Abya-Yala, Ecuador. 2006. 
LANDER, E. Los límites del planeta y la crisis civilizatoria. Contextualizaciones Latinoamericanas, v. 8, 2015.

LEFF, E. De la racionalidad económica a la crisis y de allí a las alternativas. Entrevista con Enrique Leff. Buenos Aires: Consejo Latinoamericano de Ciencias Sociales. 2009.

LINSALATA, L. Política comunitaria y rebelión en El Alto. Ciudades Rebeldes, v. 39, 2010.

LINSALATA, L. Cuando manda la Asamblea. Lo comunitario-popular en Bolivia: una aproximación desde los sistemas comunitarios de agua de Cochabamba (Tesis doctoral en Estudios Latinoamericanos. UNAM). 2014.

LINSALATA, L. De la defensa del territorio maseual a la reinvención comunitario-popular de la política: crónica de una lucha. Estudios Latinoamericanos, v. 40, p. 117-136, 2017.

LINSALATA, L. Al Yoltok: cuando el agua no es mercancía. Bajo el Volcán, v. 1, n. 28, 2018.

MACHADO, H. Los dolores de Nuestra América y la condición neocolonial. Extractivismo y biopolítica de la expropiación. En: SADER E, GENTILI P, editores. Movimientos socioambientales en América Latina. Buenos Aires: CLACSO - Consejo Latinoamericano de Ciencias Sociales; 2012. p. $51-66$.

MACHADO, H. Capitalismo, colonialismo y crisis ecológica. Crisis de la Nauraleza y naturaleza de la crisis. Síntomas. Documentos de Trabajo del CIES. Junio. 2014.

MALDONADO, B. Comunalidad y responsabilidad autogestiva. Cuadernos del sur, v. 34, p. $21-28,2013$.

MALDONADO, B. Perspectivas de la comunalidad en los pueblos indígenas de Oaxaca. Bajo el Volcán, v. 23, p. 151-159, 2016.

MARTÍNEZ LUNA, J. Origen y ejercicio de la comunalidad. Cuadernos del sur, v. 34, p. 83 90, 2013.

MARTÍNEZ LUNA, J. Eso que llaman comunalidad. Oaxaca: Secretaría de las Culturas y Artes de Oaxaca, Colección diálogos Pueblos Originarios de Oaxaca. México, 2010.

MOREANO, M; MOLINA, F; BRYANT, R. Hacia una ecología política global: aportes desde el sur. En: ALIMONDA, H; TORO, C; MARTÍN, F. coordinadores. Ecología Política Latinoamericana. Pensamiento crítico, diferencia latinoamericana y rearticulación epistémica. Vol. 1. Buenos Aires: CLACSO; México: Universidad Autónoma Metropolitana. 2017. p. 13 - 20.

NAVARRO, M. L. Mujeres comuneras en la lucha por la reproducción de la vida ante el despojo capitalista: irradiaciones del pensamiento de Silvia Federici. Bajo el Volcán, v. 1, p. 22, 2015 a.

NAVARRO, M. L. Hacer común contra la fragmentación en la ciudad: experiencias de autonomía para la reproducción de la vida. Comunes contra y más allá del capitalismo. El Apantle. Revista de Estudios Comunitarios, n, 1, p. 99 - 124, 2015b. 
NAVARRO, M. L. Hacer común contra la fragmentación en la ciudad: experiencias de autonomía urbana. Puebla: Benemérita Universidad Autónoma de Puebla, Instituto de Ciencias Sociales y Humanidades "Alfonso Vélez Pliego". 2016.

NAVARRO, M. L.; GUTIÉRREZ, R. Claves para pensar la interdependencia desde la ecología y los feminismos. Bajo el Volcán, v. 18, n. 28, 2018.

NAVARRO, M.L; TZUL TZUL, G. Introducción. El Apantle, Revista de Estudios Comunitarios, n. 2, p. 9 - 16, 2016.

OSTROM, E. Governing the commons. Cambridge: Cambridge University Press, 1990.

PARRA-ROMERO, A. ¿Por qué pensar un giro decolonial en el análisis de los conflictos socioambientales en América Latina?, Ecología Política, n. 51, p. 15 - 20, 2016.

PINEDA, E. El sentido de comunalidad y la lucha del pueblo Mixe, Eutopía: Revista de Desarrollo Económico Territorial, n. 11, p. 115-128, 2017.

PORTO-GONÇALVES, C. Lucha por la Tierra. En: ALIMONDA H, TORO C, MARTÍN F, coordinadores. Ecología Política Latinoamericana. Pensamiento crítico, diferencia latinoamericana y rearticulación epistémica. Vol. 2. Buenos Aires: CLACSO; México: Universidad Autónoma Metropolitana. 2017. p. 53-78.

RIVERA CUSICANQUI, S. Ch'ixinakax utxiwa: una reflexión sobre prácticas y discursos descolonizadores. Buenos Aires: Tinta Limón. 2010.

RIVERA-CUSICANQUI, S. Comunalidades anarquistas. una aproximación testimonial, Bogotá: V Congreso de Asociación Latinoamericana de Antropología, 2017.

ROCA-SERVAT, D. Introducción. Los comunes desde las ecología(s) política(s) del sur/Abyayala. Visibilizando alternativas al desarrollo extractivista en la región. En: ROCA-SERVAT, D; PERDOMO SÁNCHEZ, J. (Coord). La lucha por los comunes y las alternativas al desarrollo frente al extractivismo : miradas desde las ecología(s) política(s) latinoamericanas. Ciudad Autónoma de Buenos Aires: CLACSO. 2020. p. 27 - 39.

ROCA-SERVAT, D; BOTERO-MESA, M. La justicia hídrica y el desarrollo: más allá de los discursos de la economía verde, los derechos humanos neoliberales y los bienes comunes rentables. Revista Nuestramérica. 2020. Vol, 8, No. 16.

ROCA-SERVAT, D; PALACIO OCANDO, L. "Sí a La Vida, Al Agua Y Al Territorio': Relaciones Hidrosociales Alternativas en Colombia." European Review of Latin American and Caribbean Studies / Revista Europea De Estudios Latinoamericanos y del Caribe, No. 107 (2019): 117-38. https://doi.org/10.32992/erlacs.10389

SANTOS, B. S. Epistemologías del Sur. Utopía y Praxis Latinoamericana, 2011. v. 16, n. 54, p. $17-39$.

SAUNDERS, F. The promise of common pool resource theory and the reality of commons proj- 
ects. International Journal of the Commons, 2014. 8(2).

SERRANO, L; GARCÍA, A; MARÍN G. El bien común, el derecho humano al agua y las políticas de privatización [Internet]. En: El agua, como la vida, no es una mercancía. 2012 [Consultado 25 Mar 2020]. Disponible en: https:/www.ecologistasenaccion.org/?p=22492

SIWI. Stockholm Statement to Rio+20 [Internet]. 2011 [Consultado 25 Mar 2020]. Disponible en: www.worldwaterweek.org.

TORO, C; MARTíN, F. Presentación. En: ALIMONDA H, TORO C, MARTÍN F, (Coord). Ecología Política Latinoamericana. Pensamiento crítico, diferencia latinoamericana y rearticulación epistémica. Vol. 1. Ciudad Autónoma de Buenos Aires: CLACSO; México: Universidad Autónoma Metropolitana; 2017. p. 13 - 20. 
Denisse Roca-Servat

$\square$ denisse.roca@upb.edu.co

ORCiD: https://orcid.org/0000-0003-2872-6471
Submitted on: 14/06/2020

Accepted on: 18/06/2021

2021;24e:00961

\section{Juan David Arias-Henao}

\juandavidariashenao@gmail.com

ORCiD: https://orcid.org/0000-0002-0462-3964

\section{María Botero-Mesa}

$\square$ bmmaria@live.com

ORCiD: https://orcid.org/0000-0003-1361-9534

How to cite: ROCA-SERVAT, D.; ARIAS-HENAO, J.; BOTERO-MESA, M. Decolonizing hegemonic approaches of water: exploring Latin American proposals for communality and community entanglements. Ambiente \& Sociedade. São Paulo, v. 24, p. $1-20,2021$. 


\title{
Descolonizando as visões hegemônicas da água: propostas latino-americanas da comunalidade e envolvimentos comunitários
}

\author{
Denisse Roca-Servat \\ Juan David Arias-Henao \\ María Botero-Mesa
}

São Paulo. Vol. 24, 2021

Tema em destaque:

Insurgências Decolonais e Horizontes Emancipatórios: Contribuições da Ecologia Política
Resumo: A atual crise civilizacional que estamos enfrentando levanta desafios aos cuidados dos bens comuns, entre eles a água ocupa um lugar muito especial. Nesse contexto, é essencial refletir sobre ele de outras margens, nas quais visíveis diferentes abordagens epistêmicas e ontológicas são visíveis que resistem ao determinismo do capitalismo neoliberal, à monocultura da ciência eurocêntrica moderna e à dominação antropocéntrica-patriarcal da natureza. Com esse objetivo, partindo da ecologia política latino-americana, este trabalho realiza, primeiramente, uma revisão crítica das abordagens hegemônicas da água. Em seguida, duas propostas descoloniais são apresentadas em relação aos bens comuns, principalmente a água: comunalidade e envolvimentos comunitários. Finalmente, o escopo dessas propostas é discutido como alternativa à crise civilizatória e sua contribuição para a compreensão da água sob uma perspectiva descolonial, relacional e ecológica.

Palavras-chave: Ecologia política, água, descolonizar, comunalidade, envolvimentos comunitários.

Como citar: ROCA-SERVAT, D.; ARIAS-HENAO, J.; BOTERO-MESA, M. Descolonizando as visões hegemônicas da água: propostas latino-americanas da comunalidade e envolvimentos comunitários. Ambiente \& Sociedade. São Paulo, v. 24, p. 1-20, 2021. 


\title{
Descolonizando las visiones hegemónicas del agua: propuestas latinoamericanas desde la comunalidad y los entramados comunitarios
}

\author{
Denisse Roca-Servat \\ Juan David Arias-Henao \\ María Botero-Mesa
}

São Paulo. Vol. 24, 2021

Tema en Destaque:

Insurgencias Decoloniales y Horizontes Emancipatórios: Contribuiciones de la Ecología Política
Resumen: La actual crisis civilizatoria que vivimos plantea retos sobre el cuidado de los comunes, entre ellos el agua ocupa un lugar crucial. En este contexto, se hace indispensable reflexionar sobre ella desde otras orillas, en las que sean visibles distintas aproximaciones epistémicas y ontológicas que resistan el determinismo del capitalismo neoliberal, la monocultura de la ciencia moderna eurocéntrica y la dominación antropocéntrica-patriarcal de la naturaleza. Con este propósito, partiendo de la ecología política latinoamericana, este trabajo realiza en primer lugar, una revisión crítica de los enfoques hegemónicos del agua. Luego se presentan dos propuestas decoloniales de relación con los comunes, en particular con el agua: la comunalidad y los entramados comunitarios. Finalmente, se discute el alcance de estas propuestas como alternativas a la crisis civilizatoria, y su aporte a la comprensión del agua desde una perspectiva decolonial, relacional y ecológica.

Palabras-clave: Ecología política, agua, descolonizar, comunalidad, entramados comunitarios.

Como citar: ROCA-SERVAT, D; ARIAS-HENAO, J; BOTERO-MESA, M. Descolonizando as visões hegemônicas da água: propostas latino-americanas da comunalidade e envolvimentos comunitários .Ambiente \& Sociedade. São Paulo, v. 24, p. 1-22, 2021.

DOI: http://dx.doi.org/10.1590/1809-4422asoc20200096r1vu2021L4TD 